\title{
Estimation of Geothermal Gradient, Geothermal Heat Flux and Thermal Conductivity of Rocks in Western Niger Delta Using Well Log Data
}

\author{
Nnorom .S. Lotanna ${ }^{1 *} \quad$ Eze Stanley $^{2} \quad$ Saleh. A. Saleh ${ }^{3} \quad$ John. J. Osazee ${ }^{4}$ \\ 1. Department of Earth Sciences, Federal University of Petroleum Resources, Effurun, Nigeria \\ 2.Department of Geology, University of Port Harcourt, Port Harcourt, Nigeria \\ 3.Department of Petroleum Engineering and Geosciences, Petroleum Training Institute, Effurun, Nigeria \\ 4.Department of Physics, University of Benin, Benin City, Nigeria \\ *E-mail of the corresponding author: *lotanna_nnorom@yahoo.com; uchechukwueze2014@gmail.com
}

\begin{abstract}
This study presents the result of the estimation of heat flow from six (6) wells (Well X:001 to 006) in SouthWestern Niger Delta using values of Geothermal gradient (GG), Geothermal heat flux (Q) and thermal conductivity (K) computed from Sonic and continuous temperature log data for each well. Geothermal gradient was computed from continuous temperature logs using the simple gradient method while geothermal heat flux and thermal conductivity of the rocks in the wells were computed from the sonic log data, using the Relative Heat Flow Model and Fourier One-dimensional Heat Flow Law respectively. The results were analysed and interpreted to investigate the thermal structure and pattern of heat flow distribution of the basin. Results showed that geothermal gradient ranges from $1.45^{\circ} \mathrm{C} / 100 \mathrm{~m}$ to a value of $1.61^{\circ} \mathrm{C} / 100 \mathrm{~m}$, with a simple average of $1.55^{\circ} \mathrm{C} / 100 \mathrm{~m}$. Geothermal gradient contour map computed from this result, showed a low thermal gradient at the northern part of the study area where we have Well X-006 and increases outwards in all direction as we move further offshore. These differences reflect changes in thermal conductivity of rocks, ground water movement and endothermic reaction during diagenesis, since geothermal gradient is influenced by lithology or differential rate of sedimentation. Therefore, it was inferred that sediments with a relatively high geothermal gradient (1.55 to $1.61^{\circ} \mathrm{C} / 100 \mathrm{~m}$ ) will mature earlier (low oil window) than those with low thermal gradient values. By implication, a high geothermal gradient enhances the early formation of oil at relatively shallow burial depths, but causes the depth range of the oil window to be narrow, while low geothermal gradient causes the first formation of oil to begin at fairly deep subsurface levels, but makes the oil window broad. Geothermal heat flux estimated from subsurface temperature and one-way sound travel time, shows heat flux varying between $33.16 \mathrm{mWm}^{-2}$ to 72.73 $\mathrm{mWm}^{-2}$ with a simple average of $48.43 \mathrm{mWm}^{-2}$. Low heat flux was observed at the central part of the study area which increases towards the western and eastern parts of the area with Well X-005 characterized by a higher geothermal heat flux. Therefore, it was inferred that the western and eastern parts of the study area with higher heat flux values may be characterized as zones with maximum sediment thickness and are characterized as having depressions (gravity low) on the geoid which is characteristics of a basin, while the central part of the study area with low heat flux values correspond with zones of minimum sediment thickness. Also, thermal conductivity of rocks in the study area computed directly from heat flux and geothermal gradient results, ranges from $2.28 \mathrm{~W} / \mathrm{m}^{\circ} \mathrm{C}$ to $4.76 \mathrm{~W} / \mathrm{m}^{0} \mathrm{C}$ with an average of $3.19 \mathrm{~W} / \mathrm{m}^{0} \mathrm{C}$. Thermal conductivity contour map computed from this result, showed low thermal conductivity values observed at the central part of the study area, and increases outwards towards the west and eastern parts. This pattern of thermal conductivity variation suggests probably there exists heavy crude oil at the central part of the study area and lighter crude oil as we move outward in all direction. It was also observed that within each well, thermal conductivity increased with depth and decreased with porosity which may be caused by difference in lithology and fluid content, due to the fact that all pore fillers (i:e gases and liquids) are poor conductors. The estimated values of geothermal gradient, heat flux and thermal conductivity obtained in this study are similar to the results obtained from previous studies in the region and with other passive continental margins of the world.
\end{abstract}

Keywords: Heat flow, Geothermal Gradient, Geothermal Heat Flux, Thermal Conductivity, Continuous Temperature and Sonic log.

DOI: $10.7176 / \mathrm{JETP} / 10-2-04$

Publication date: April $30^{\text {th }} 2020$

\section{Introduction}

The Niger Delta Basin is one of the most petroliferous and economic sedimentary basin in Nigeria, as majority of the present day petroleum reserves in Nigeria (onshore and offshore) are derived from the basin. The marked increase in exploration activity in the basin over the years have shown the renewed interest in the hydrocarbon potential and prospectivity of the region. Considering the abundance of hydrocarbon reserves in the basin, analysis of all available data will go a long way in reducing exploration risks and uncertainties associated with the 
development of its hydrocarbon reserves.

The estimation of heat flow in sedimentary basins is important for the investigation of the geothermal resource potential of such basin. Geothermal gradient is defined as the rate at which the earth's temperature increases with depth. Among all other sources, the earth's heat is believed to have being derived from the decay of radioactive elements, impact and compression of the earth in the release of meteorites and heat released from the electromagnetic effects of the earth's magnetic field. There are variations in geothermal gradient from place to place. It is determined from the measurement of temperature of rocks penetrated by borehole after drilling, when the drilling fluids have reached the ambient temperature but this is not always achievable for practical reasons (Lachenbruch and Brewer 1959; Ramey 1962; Raymond 1969, as cited by Adedapo et al., 2013). Temperature measurements made during drilling fluid circulation, underestimates the actual formation temperature as the cold drilling fluid invades the rock formation and cools it down very efficiently via heat convection (Lachenbruch and Brewer 1959). Also, temperature measurements made on wireline logs shortly after drilling fluid circulation has stopped, underestimates the actual formation temperature as the mass of rock formation around the borehole reheats the borehole and drilling fluid up to its ambient temperature via heat conduction (Lachenbruch and Brewer 1959; Ramey 1962; Raymond 1969). This process is slow and less efficient compared to heat convection. Therefore, temperature measurements made at increasing times after the shut-in time (duration of the drilling fluid circulation period) are much closer to the real formation temperature.

The knowledge of the geothermal gradient and formation temperature of a place is key to understanding the regional/sub-regional tectonics and thermal regime in the area, the critical elements that characterizes the geothermal system of the area, determination of physical properties of reservoir fluids, predictions of gas hydrate prone zones, well log interpretation and evaluation of geothermal energy resources (Kutasov and Eppelbaum 2005), and also determination of the suitability of such places for siting geothermal plants for the generation of electricity that can be utilize for industrial, domestic and recreational activities. A geothermal system is made up of the following elements: a heat source (which is usually a shallow magmatic body, cooling and often partially molten); a geothermal reservoir (the rock volume through which heat can be extracted, it usually contains hot fluids moving under buoyancy); hot fluids (liquids or gases that are hydraulically connected with the reservoir and act as the carrier of heat) and a recharge area (usually a colder rock containing water at a lower temperature). Geothermal studies can also be applied in the investigation and predictions of zones that can house petroleum/crude oil and modelling of hydrocarbon generation, migration and maturation. However, the representation of heat flow data on contour maps aid in the interpretation of the thermal structure, crustal tectonics and large-scale hydrodynamics, and formation of basins (Lachenbruch and Sass 1977).

Several studies on estimation of heat flow data have been documented. Nwachukwu (1976), calculated geothermal gradients using 1000 well logs from the Niger Delta Basin and obtained geothermal gradients that range between 0.7 to $1.0^{\circ} \mathrm{F} / 100 \mathrm{ft}$ at the centre of the delta and then increases to about $3^{\circ} \mathrm{F} / 100 \mathrm{ft}$ in the Cretaceous rocks on the north. Etim et al., (1996), estimated the heat flux for the Northern Niger Delta Basin using the Thermal Resistance method proposed by Bullard (1939) and Chapman et al., (1984) and arrived at heat flux values ranging between $38.70 \mathrm{mWm}^{-2}$ and $64.28 \mathrm{mWm}^{-2}$ with an average of $51.49 \mathrm{mWm}^{-2}$. Also Ogagarue, (2007) estimated heat flow from twenty-one (21) wells in the western Niger Delta onshore using the Relative Heat Flow Model of Houbolt and Wells, (1980) and arrived at heat flux values ranging between $27.6 \mathrm{mWm}^{-2}$ and $68.3 \mathrm{mWm}^{-2}$ with an average of $43.92 \mathrm{mWm}^{-2}$ which was observed to decrease towards the coast of the region. Etim and Akpabio, (2009) also estimated the heat flow in the North-western Niger Delta Basin from eight (8) wells using the Fourier One-dimensional Heat Flow Law and arrived at heat flux values ranging between $38.7 \mathrm{mWm}^{-2}$ and $72.4 \mathrm{mWm}^{-2}$ with a simple average of $56.1 \mathrm{mWm}^{-2}$. From the preceding literatures, observation shows that heat flow estimates were made using a single heat flow parameter i:e geothermal gradient, geothermal heat flux or thermal conductivity within the respective study areas. In this present study, a combination of Geothermal gradient $\left(\mathrm{GG}\right.$ in $\left.{ }^{\circ} \mathrm{C} / 100 \mathrm{~m}\right)$, Geothermal heat flux $\left(\mathrm{Q}\right.$ in $\left.\mathrm{mW} / \mathrm{m}^{2}\right)$ and thermal Conductivity $\left(\mathrm{K}\right.$ in $\left.\mathrm{W} / \mathrm{m}^{\circ} \mathrm{C}\right)$ estimates will be used to determine the pattern of heat flow distribution in the study area. The data used in this study consists of continuous temperature and sonic log data from six (6) wells in South-Western Niger Delta. The techniques used in this study for the estimation of each heat flow parameter includes the Simple gradient method for estimation of geothermal gradient (GG), Houbolt and Wells (1980) Relative heat flow model for estimation of Geothermal heat flux (Q) and Fourier one-dimensional heat flow law for thermal conductivity $(\mathrm{K})$ estimates. A combination of these three parameters will give a better estimate of heat flow in the study area and by implication contribute to the existing literatures on heat flow estimation within the Niger Delta region.

\section{Geologic Setting}

The Study area "X-field" is located within the South-Western part of the Niger Delta basin. The Niger Delta, a large arcuate delta, is located at the South-Eastern end of Nigeria, bordering the Atlantic Ocean. It is however, situated at the West African Margin of the Gulf of Guinea and extends from latitude $4-6^{0} \mathrm{~N}$ and longitude 3 $9^{0} \mathrm{E}$. The basin is bounded to the east by the Calabar Flank (Nwachukwu and Chukwura, 1986), to the west by the 
Benin Basin, to the south by the Gulf of Guinea and finally to the north by the Anambra Basin and other Cretaceous tectonic structures i:e Abakaliki Anticlinorium and Afikpo Syncline (Evamy et al., 1978). Its tectonic frame work is attributed to stresses that followed the separation of the African and South American plates which brought about the opening of the South Atlantic. The delta however, covers an estimated area of about $105,000 \mathrm{~km}^{2}$.

The early Niger Delta is interpreted as being a river-dominated delta, however the post-Oligocene delta is a typical wave-dominated delta with well-developed shoreface sands, beach ridges, tidal channels, mangrove and freshwater swamps (Orife and Avbovbo 1982; Avbovbo 1978; Tamuko 2008). It is one of the world's largest deltas and shows an overall upward transition from marine shales (Akata Formation) through a sand-shale paralic interval (Agbada Formation) to continental sands of the Benin Formation (Michele et al., 1999; Avbovbo 1978). Depending on relative sea level changes, local subsidence and sediment supply, the delta experiences episodes of regressions and transgressions (Nadin and Kusznir 1995; as cited by Tamuko 2008).

Based on intensive study, the sedimentary deposits in the Niger Delta Basin is divided into three (3) main large-scale lithostratigraphic units which are: the basal Paleocene - Recent pro-delta facies of the Akata Formation which is mainly composed of sequence of under-compacted marine shales, clay and silt, with depth from about 11,121ft; the Eocene - Recent paralic facies of the Agbada Formation comprising of an alternation of sands (coastal and/or fluviomarine), silts, clays and marine shales, with depth range of $7180-11,121 \mathrm{ft}$; and the Oligocene - Recent fluvial/continental facies of the Benin Formation composed of massive continental/Coastal plain sands with an average thickness of about 0 - 6000ft (Doust 1989; Evamy et al., 1978; Stacher 1995; Weber and Daukoru 1975; Whiteman 1982).

The Niger Delta Complex is characterized by large-scale syn-sedimentary features. These include growth faults and the associated roll-over anticlines which form exploration targets since these roll-over structures provide suitable trapping mechanism for hydrocarbon accumulation.

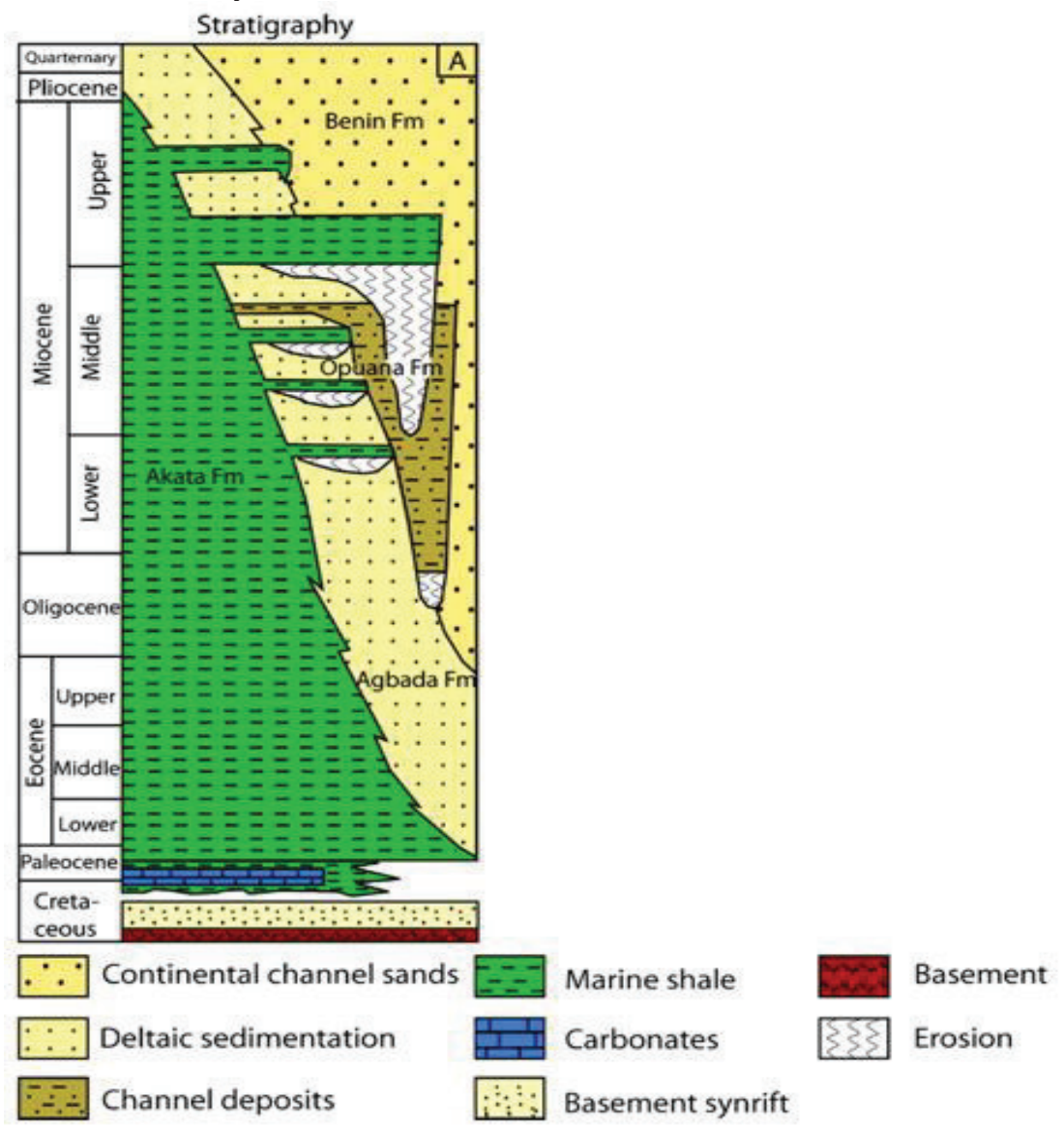

Figure 1: Lithostratigraphy Units of the Niger Delta. (After Avobovbo, 1978, as modified by Lawrence et al., (2002) and Corredor et al., (2005)).

\section{Dataset and Methodology}

\subsection{Dataset}

The data used for this study consists of a set of continuous temperature log and sonic log data obtained from six (6) wells (Well X-001 to X-006) in the South-western Niger Delta, provided by Shell Petroleum Development Company (SPDC), Port-Harcourt, Nigeria. Figure 2 shows the map of Niger Delta showing the study area, while 
Figure 3 is the base map of the study area showing the well positions.

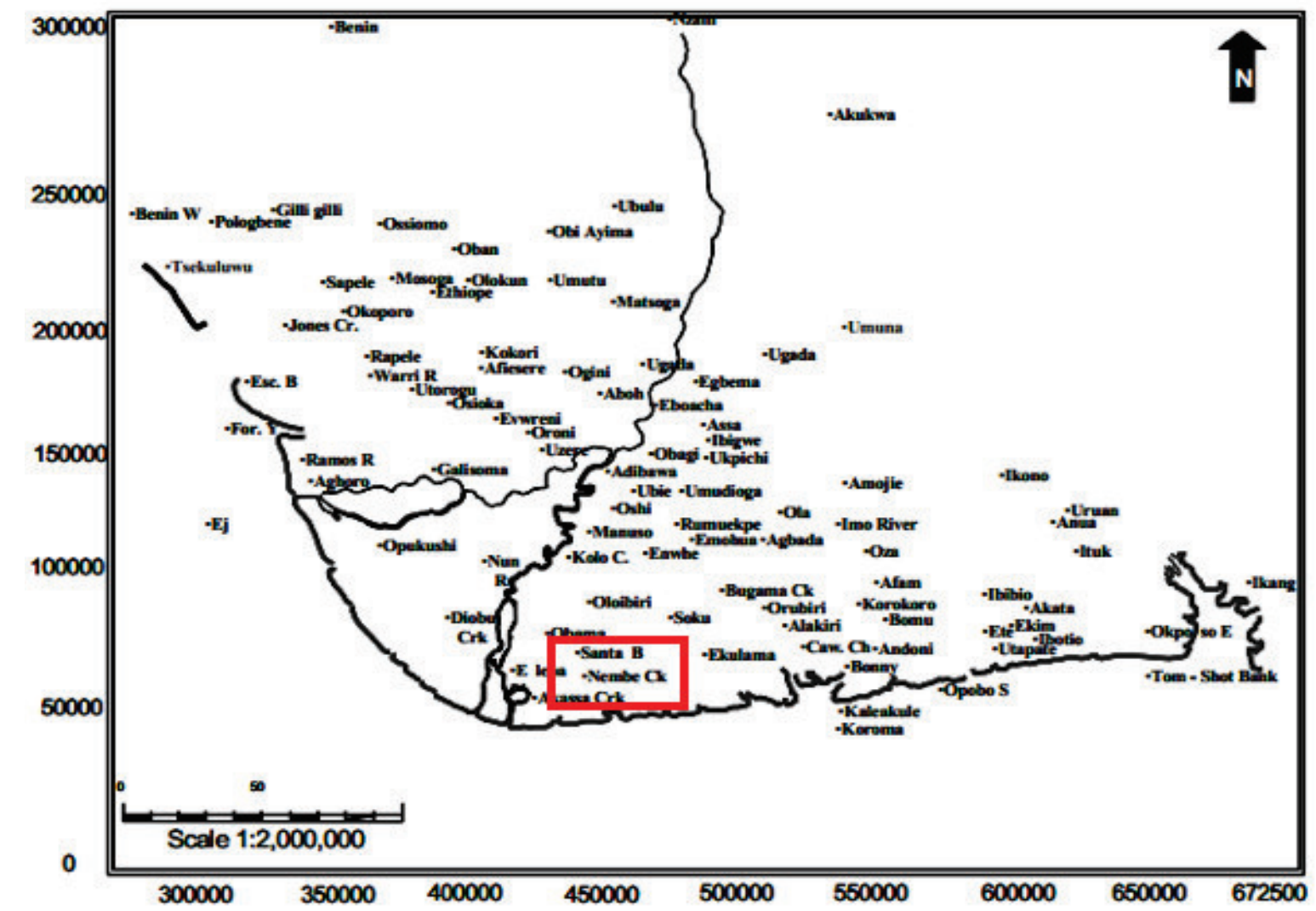

Figure 2: The Niger Delta Map, showing the study area in red (Modified after Akpabio et al., 2013)

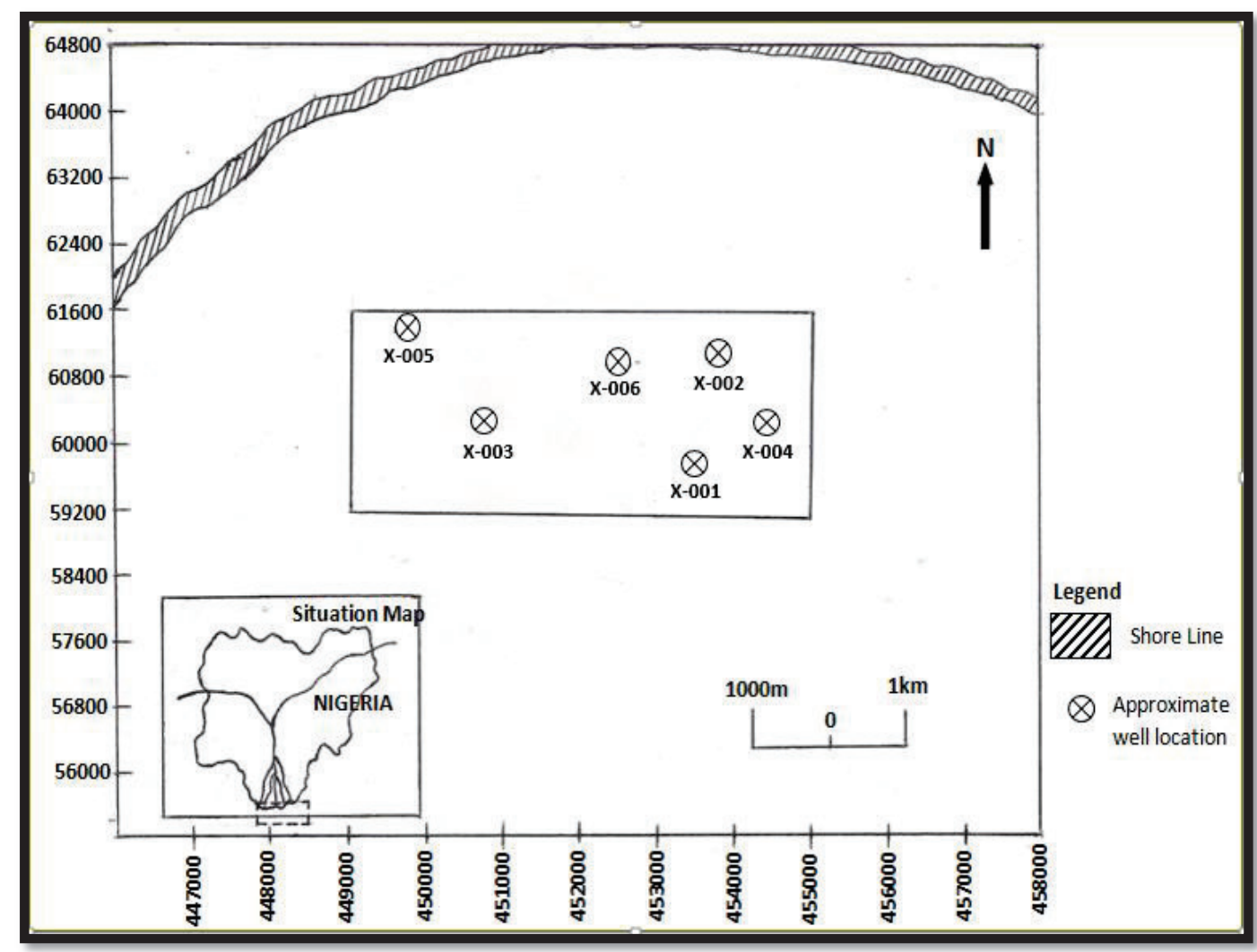

Figure 3: Base map of the study area showing the well positions (Well X-001 to X-006).

In this study, Continuous temperature log was used instead of Bottom-Hole Temperature (BHT) logs because 
no temperature correction is required on the raw temperature data and continuous temperature log measurements are made when enough time has elapsed between the period of drilling the well and when the temperature measurements are made. As such thermal equilibrium has been attained between the heating effect of the rock formation and cooling effect of the drilling fluid in the borehole. The data therefore do not need to be corrected for drilling disturbances (Lachenbruch and Brewer 1959).

\subsection{Methodology}

The estimation of heat flow in this study was carried out from estimates of three heat flow parameters which are Geothermal gradient (GG), Geothermal heat flux (Q) and Thermal conductivity (k) for six (6) wells. Geothermal gradient (GG) is defined as the rate of increase in temperature per unit depth in the earth due to the outflow of heat from the earth's center. Geothermal gradient was obtainable from continuous temperature log data from each well using the Simple Gradient Method.

The Simple Gradient Method is given as:

Where;

$$
T_{F}=G G \times Z+S
$$

$\mathrm{GG}=$ Geothermal gradient

$\mathrm{Z}=$ Formation depth

$\mathrm{S}=$ Mean annual surface temperature

$\mathrm{T}(\mathrm{F})=$ Formation temperature $\left(\right.$ in $\left.^{\circ} \mathrm{F}\right)$ as read from the log

By re-arranging the terms in equation (1) Geothermal gradient (GG) is given as:

$$
G G=\frac{T_{F}-S}{Z}
$$

In estimating the geothermal gradient, the temperature at a depth (in feet) for each well was read from the log at the particular depth and recorded against the depth. The temperatures were read at every $100 \mathrm{ft}$ from the temperature logs. Also, since the temperatures are logged in ${ }^{0} \mathrm{~F}$ and because the simple gradient method requires the temperature to be in ${ }^{0} \mathrm{C}$, the relation below was used to convert the temperatures to values in ${ }^{0} \mathrm{C}$;

$$
{ }^{\circ} \mathrm{C}=\frac{5}{9}\left({ }^{\circ} \mathrm{F}-32\right)
$$

After obtaining the temperature at a depth $\mathrm{Z}$ in ${ }^{0} \mathrm{C}$, the geothermal gradient at that depth would then be obtained using the relation:

$$
G G=\frac{100}{Z(f t) * 0.305(m)}\left({ }^{\circ} \mathrm{C}-S\right)(4)
$$

Where GG is the Geothermal gradient in $\left({ }^{\circ} \mathrm{C} / 100 \mathrm{~m}\right)$ and $\mathrm{S}$ is the mean surface temperature. The mean surface temperature used for all the wells in this study is $27^{\circ} \mathrm{C}$; and this is due to the fact that the average atmospheric temperature in the Niger Delta is approximately $27^{\circ} \mathrm{C}$ (Nwachukwu, 1976; Avbovbo, 1978; Evamy et al., 1978; Etim et al., 1996).

Geothermal heat flux (Q) was obtained using the Relative Heat Flow Model of Houbolt and Wells, (1980) which estimates heat flux (Q) in terms of recorded subsurface temperature and one-way sound travel time $(\mathrm{t})$ obtained from sonic log data. The Relative Heat Flow Model is given by the expression below:

Where,

$\mathbf{Q}$ is the Relative heat flux in Boderij Unit (BU).

a $\&$ c are constant with values of 1039 and 80.031 respectively.

$\mathbf{T}_{\mathbf{U}}$ is the temperature $\left(\right.$ in ${ }^{0} \mathrm{C}$ ) at the shallow interval of any two chosen depth interval along the wellbore

$\mathbf{T}_{\mathbf{L}}$ is the temperature (in ${ }^{0} \mathrm{C}$ ) at the deeper interval between any two chosen depth intervals along the wellbore

$\mathbf{t}_{\mathbf{U}} \boldsymbol{\&} \mathbf{t}_{\mathbf{L}}$ are the one-way travel time (in secs) at the shallower and deeper intervals of any two chosen depth intervals along the well.

Mathematically, $1 \mathrm{BU}=77 \mathrm{mWm}^{-2}$ in S.I unit. Therefore, the heat flow values obtained were multiplied by this value to express it in S.I unit.

In other to obtain one-way travel time (secs) from sonic $\log$ (in $\mu \mathrm{sec} / \mathrm{ft}$ ) as required by the above equation, the velocity $(\mathrm{m} / \mathrm{s})$ of sound waves in the wellbore formation was estimated from sonic log data using the expression below:

$$
\mathrm{V}(\mathrm{m} / \mathrm{s})=\left[\frac{1000000 * 0.305}{\Delta \mathrm{t}}\right]
$$

Where $\Delta \mathrm{t}$ is the interval transit time $(\mu \mathrm{sec} / \mathrm{ft})$ obtained from the sonic log.

The obtained velocity values were however used to obtain the one-way sound travel time (t-secs) at different depths in the wellbore using the expression below:

$$
\mathrm{t}(\mathrm{sec})=\frac{\mathrm{Z}(\mathrm{m})}{\mathrm{V}(\mathrm{m} / \mathrm{s})}
$$

Due to the large volume of data from each well, calculation of one-way travel time was made per $100 \mathrm{ft}$ depth for 
the purpose of simplicity. In addition, to choose the best/appropriate depth interval for heat flow estimation as required by the relative heat flow model, the one-way travel time was plotted against depth for each well, with a best fit line drawn through the points. Points which were much separated and falls on the best fit line were then chosen with their corresponding depth, one-way travel time and temperature values and were used in the estimation of heat flow within such intervals. Also, it is important to note that errors may arise in the estimated heat flow due to uncertainty estimate of the Boderij Unit (BU) and from the values of the constants a \& $\mathrm{c}$ which are both statistically derived (Houbolt and Wells, 1980; Ogagarue, 2007).

Also, thermal conductivity $(\mathrm{K})$ was estimated in this study. Estimation of thermal conductivity was made using the Fourier One-Dimensional Heat Flow Law which defines thermal conductivity as the quantity of heat flowing through a unit area of the rock per unit geothermal gradient, and given as:

Where;

$$
K=\frac{q}{\partial t / \partial z}
$$

$\mathrm{q}=$ Heat flow (or geothermal heat flux).

$\partial t / \partial z=$ Geothermal gradient.

$\mathrm{K}=$ Rock's thermal conductivity.

The use of the Fourier One-dimensional heat flow law in the estimation of thermal conductivities of rocks not only removes the difficulty of having to make laboratory thermal conductivity measurements and the uncertainty of insitu conductivity simulations from such measurements, but also to remove the problem of having to correct for effects such as vertical water flow, erosion and sedimentation, uplift, climatic change, effects of lakes, rivers and other regions of anomalous temperatures, and other steady state effects of topographic relief and thermal refraction in dissimilar rocks which could possibly cause departures in heat flow estimation over a particular region.

\section{RESULTS AND DISCUSSION}

\subsection{Results}

Figure 4 (a-f) is a plot of one-way travel time versus depth for the various wells showing the best fit line used for estimation of heat flux. Table 1 (a-f) shows the results of Computed Heat Flux values for each well while Table 2 shows the result of average values of geothermal gradient, heat flux and thermal conductivity values obtained from Well: X-001 to X-006 in the study area. 

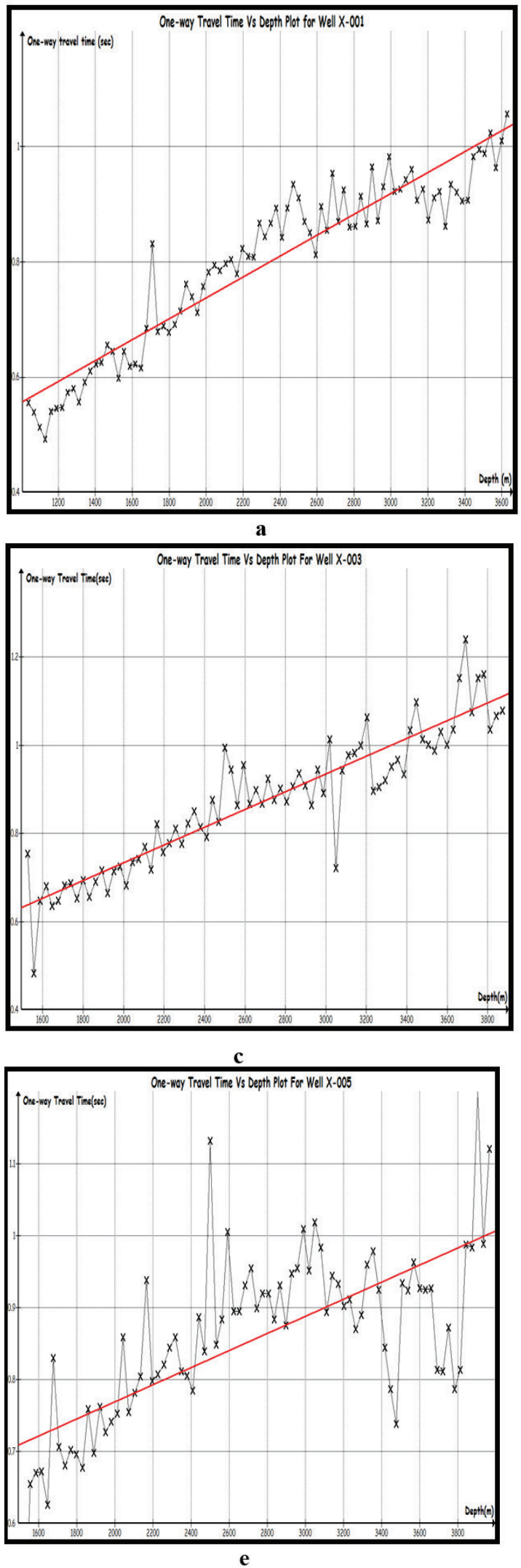

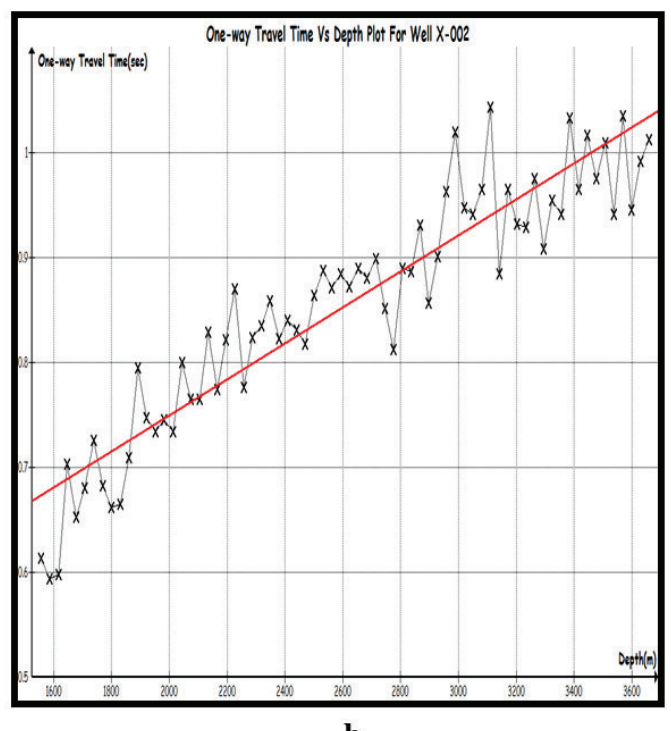

b

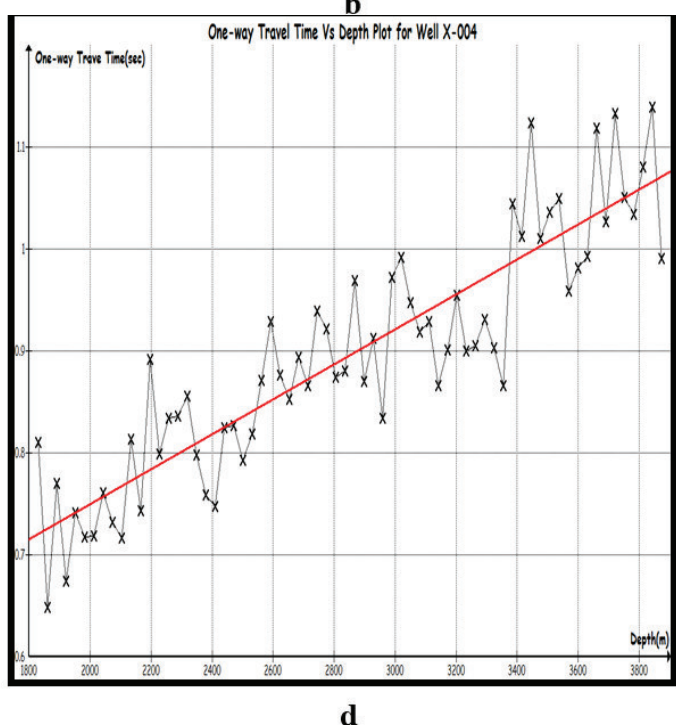

d

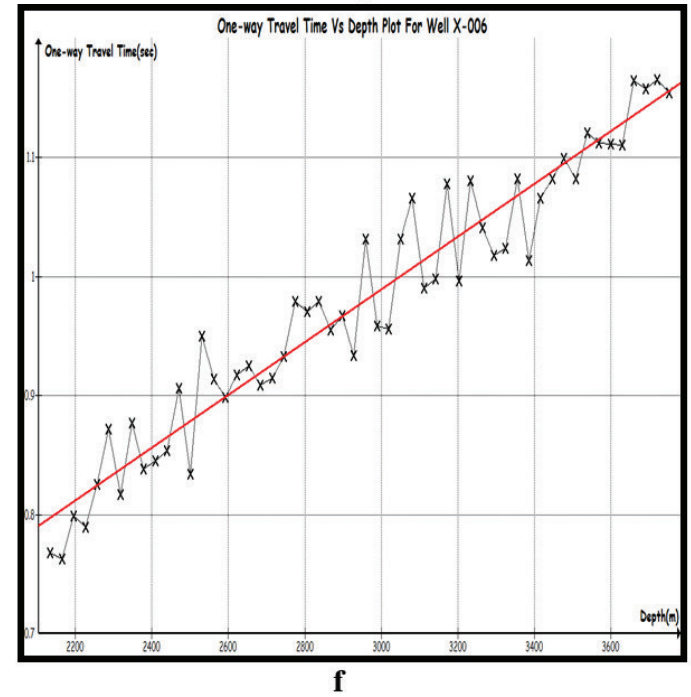

Figure 4 a, b, c, d, e, f: One-way travel time versus depth plots for Wells: X-001; X-002, X-003, X-004, X-005 and $\mathrm{X}-006$, showing the best fit line. Intervals which are well separated and falls on the best fit line were picked and used for estimation of heat flux. 
Tables 1: a, b, c, d, e and f: Showing results of Computed Heat Flux values for each well (Well: X-001 to 006 ) in the study area.

a

\begin{tabular}{|c|c|c|c|c|}
\hline \multicolumn{5}{|c|}{ Well: X-001 } \\
\hline Depth (m) & $\begin{array}{c}\text { Temp } \\
\left({ }^{\circ} \mathrm{C}\right)\end{array}$ & $\begin{array}{c}\text { One-way } \\
\text { travel time } \\
\text { (sec) }\end{array}$ & Interval & $\begin{array}{l}\text { Heat Flux } \\
\left(\mathrm{mW} / \mathrm{m}^{2}\right)\end{array}$ \\
\hline \multirow[t]{2}{*}{1494.5} & 52.06 & 0.6448 & & \\
\hline & & & P1 & 25.69 \\
\hline \multirow[t]{2}{*}{1860.5} & 55.31 & 0.7149 & & \\
\hline & & & $\mathrm{P} 2$ & 42.39 \\
\hline \multirow[t]{2}{*}{2653.5} & 66.58 & 0.8548 & & \\
\hline & & & P3 & 51.96 \\
\hline 3019.5 & 73.77 & 0.9230 & & \\
\hline \multicolumn{4}{|c|}{ Average Heat Flux } & 40.01 \\
\hline
\end{tabular}

c

\begin{tabular}{|c|c|c|c|c|}
\hline \multicolumn{5}{|c|}{ Well: X-003 } \\
\hline $\begin{array}{c}\text { Depth } \\
(\mathrm{m})\end{array}$ & $\begin{array}{c}\text { Temp } \\
\left({ }^{\circ} \mathrm{C}\right)\end{array}$ & $\begin{array}{c}\text { One-way travel } \\
\text { time }(\mathrm{sec})\end{array}$ & Interval & $\begin{array}{c}\text { Heat Flux } \\
\left(\mathrm{mW} / \mathrm{m}^{2}\right)\end{array}$ \\
\hline 1586 & 52.74 & 0.6478 & & \\
\hline & & & $\mathrm{P} 1$ & 23.08 \\
\hline 1799.5 & 54.66 & 0.6939 & & \\
\hline & & & $\mathrm{P} 2$ & 32.88 \\
\hline 2226.5 & 59.78 & 0.7779 & & 40.63 \\
\hline & & & $\mathrm{P} 3$ & \\
\hline 2470.5 & 63.46 & 0.8253 & & 44.63 \\
\hline & & & $\mathrm{P} 4$ & \\
\hline 2684 & 67.15 & 0.8674 & & 53.77 \\
\hline \multicolumn{5}{|c|}{ Average Heat Flux } \\
\hline 3721 & 91.06 & 1.0749 & $\mathrm{P} 5$ & 38.99 \\
\hline \multicolumn{5}{|c|}{$\mathrm{e}$} \\
\hline
\end{tabular}

Well: X-005

\begin{tabular}{|c|c|c|c|c|}
\hline \multicolumn{5}{|c|}{ Well:X-005 } \\
\hline Depth (m) & Temp $\left.{ }^{\circ} \mathrm{C}\right)$ & One-way travel time $(\mathrm{sec})$ & Interval & Heat Flux $\left(\mathrm{mW} / \mathrm{m}^{2}\right)$ \\
\hline 1921.5 & 55.92 & 0.7617 & & \\
\hline & & & $P 1$ & 60.08 \\
\hline 2104.5 & 58.11 & 0.7814 & & \\
\hline & & & $P 2$ & 59.49 \\
\hline 2348.5 & 61.52 & 0.8117 & & \\
\hline & & & $P 3$ & 76.89 \\
\hline 2897.5 & 71.20 & 0.8755 & & \\
\hline & \multicolumn{5}{|c|}{ Average Heat Flux } & $P 4$ & 94.44 \\
\hline 3843 & 94.46 & 0.9878 & & 72.73 \\
\hline \multicolumn{5}{|c|}{}
\end{tabular}

b

\begin{tabular}{|c|c|c|c|c|}
\hline \multicolumn{5}{|c|}{ Well: X-002 } \\
\hline Depth (m) & $\begin{array}{c}\text { Temp } \\
\left({ }^{\circ} \mathrm{C}\right)\end{array}$ & $\begin{array}{c}\text { One-way } \\
\text { travel time } \\
\text { (sec) }\end{array}$ & Interval & $\begin{array}{l}\text { Heat Flux } \\
\left(\mathrm{mW} / \mathrm{m}^{2}\right)\end{array}$ \\
\hline \multirow[t]{2}{*}{1982.5} & 56.66 & 0.7453 & & \\
\hline & & & P1 & 40.85 \\
\hline \multirow[t]{2}{*}{2104.5} & 58.15 & 0.7650 & & \\
\hline & & & $\mathrm{P} 2$ & 46.48 \\
\hline \multirow[t]{2}{*}{2806} & 69.43 & 0.8900 & & \\
\hline & & & P3 & 62.48 \\
\hline 3507.5 & 85.28 & 1.0096 & & \\
\hline \multicolumn{4}{|c|}{ Average Heat Flux } & 49.94 \\
\hline
\end{tabular}

\begin{tabular}{|c|c|c|c|c|}
\hline \multicolumn{5}{|c|}{ Well: X-004 } \\
\hline $\begin{array}{c}\text { Depth } \\
(\mathrm{m})\end{array}$ & $\begin{array}{c}\text { Temp } \\
\left({ }^{\circ} \mathrm{C}\right)\end{array}$ & $\begin{array}{c}\text { One-way travel time } \\
(\mathrm{sec})\end{array}$ & Interval & $\begin{array}{c}\text { Heat Flux } \\
\left(\mathrm{mW} / \mathrm{m}^{2}\right)\end{array}$ \\
\hline 1952 & 56.30 & 0.7414 & & \\
\hline & & & $\mathrm{P} 1$ & 42.68 \\
\hline 2440 & 62.98 & 0.8245 & & \\
\hline & & & $\mathrm{P} 2$ & 57.50 \\
\hline 2714.5 & 67.72 & 0.8665 & & \\
\hline & & & $\mathrm{P} 3$ & 45.32 \\
\hline 2928 & 71.88 & 0.9119 & & 66.47 \\
\hline & & & $\mathrm{P} 4$ & \\
\hline 3202.5 & 77.86 & 0.9550 & $\mathrm{P} 5$ & 66.05 \\
\hline \multicolumn{5}{|c|}{ Average Heat Flux } \\
\hline 3751.5 & 91.93 & 1.0507 & & 55.61 \\
\hline \multicolumn{5}{|c|}{$\mathbf{f}$} \\
\hline
\end{tabular}

\begin{tabular}{|c|c|c|c|c|}
\hline \multicolumn{5}{|c|}{ Well: X-006 } \\
\hline $\begin{array}{c}\text { Depth } \\
(\mathrm{m})\end{array}$ & $\begin{array}{c}\text { Temp } \\
\left({ }^{\circ} \mathrm{C}\right)\end{array}$ & $\begin{array}{c}\text { One-way travel time } \\
(\mathrm{sec})\end{array}$ & Interval & $\begin{array}{c}\text { Heat Flux } \\
\left(\mathrm{mW} / \mathrm{m}^{2}\right)\end{array}$ \\
\hline 2257 & 60.09 & 0.8253 & & \\
\hline & & & $\mathrm{P} 1$ & 32.03 \\
\hline 2592.5 & 64.57 & 0.8981 & & \\
\hline & & & $\mathrm{P} 2$ & 28.67 \\
\hline 2745 & 66.54 & 0.9331 & & \\
\hline & & & $\mathrm{P} 3$ & 29.80 \\
\hline 2897.5 & 68.58 & 0.9674 & & \\
\hline & & & $\mathrm{P} 4$ & 36.18 \\
\hline 3568.5 & 79.48 & 1.1124 & & 39.12 \\
\hline \multicolumn{5}{|c|}{ Average Heat Flux } \\
\hline 3751.5 & 83.06 & 1.1545 & & 33.16 \\
\hline \multicolumn{5}{|c|}{} \\
\hline
\end{tabular}

Table 2. Showing result of average values of Computed geothermal gradient (GG), geothermal heat flux (Q) and thermal conductivity (K) obtained from each well (Well: X-001 to X-006) in the study area.

\begin{tabular}{|c|c|c|c|}
\hline WELLS & $\begin{array}{l}\text { AVG. GEOTHERMAL } \\
\text { GRADIENT }\left({ }^{0} \mathrm{C} / 100 \mathrm{~m}\right)\end{array}$ & $\begin{array}{c}\text { AVG. HEAT FLUX } \\
\left(\mathrm{mW} / \mathrm{m}^{2}\right)\end{array}$ & $\begin{array}{c}\text { AVG.THERMAL } \\
\text { CONDUCTIVITY }\left(\mathrm{W} / \mathrm{m}^{0} \mathrm{C}\right)\end{array}$ \\
\hline Well X-001 & 1.610656115 & 40.01229851 & 2.631862238 \\
\hline Well X-002 & 1.546115758 & 49.93914939 & 3.278112209 \\
\hline Well X-003 & 1.565037038 & 38.99845962 & 2.559466935 \\
\hline Well X-004 & 1.56156499 & 55.60595333 & 3.599110631 \\
\hline Well X-005 & 1.571523417 & 72.72595875 & 4.755155941 \\
\hline Well X-006 & 1.453536687 & 33.15952387 & 2.279393843 \\
\hline
\end{tabular}


(a) Geothermal Gradient vs Depth plot for X-001

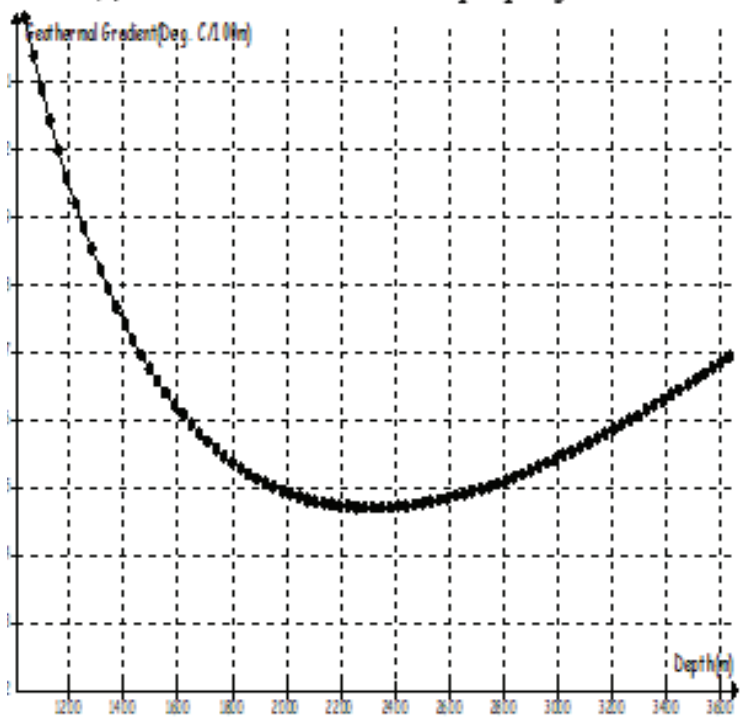

(c) Geothermal Gradient vs Depth plot for X-003

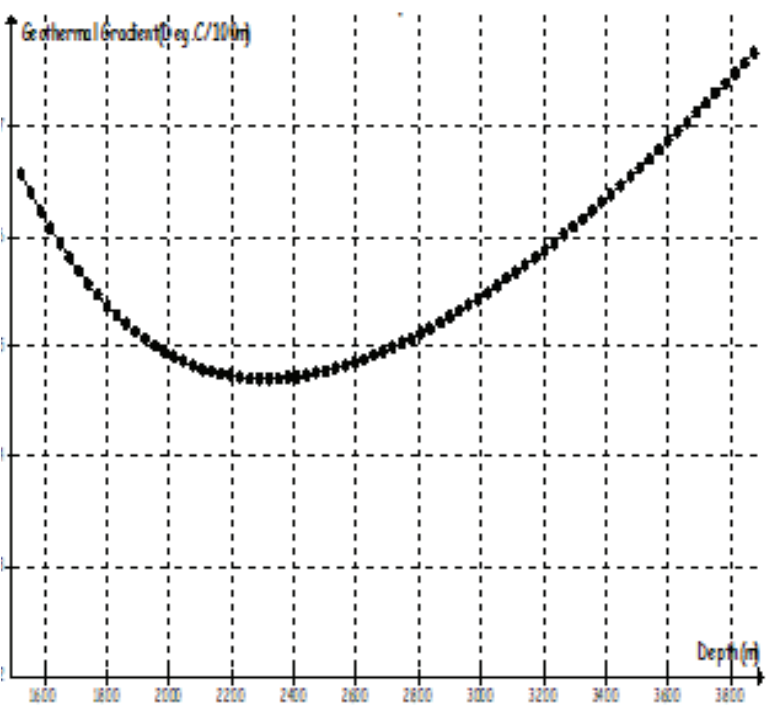

(e) Geothermal Gradient vs Depth plot for X-005

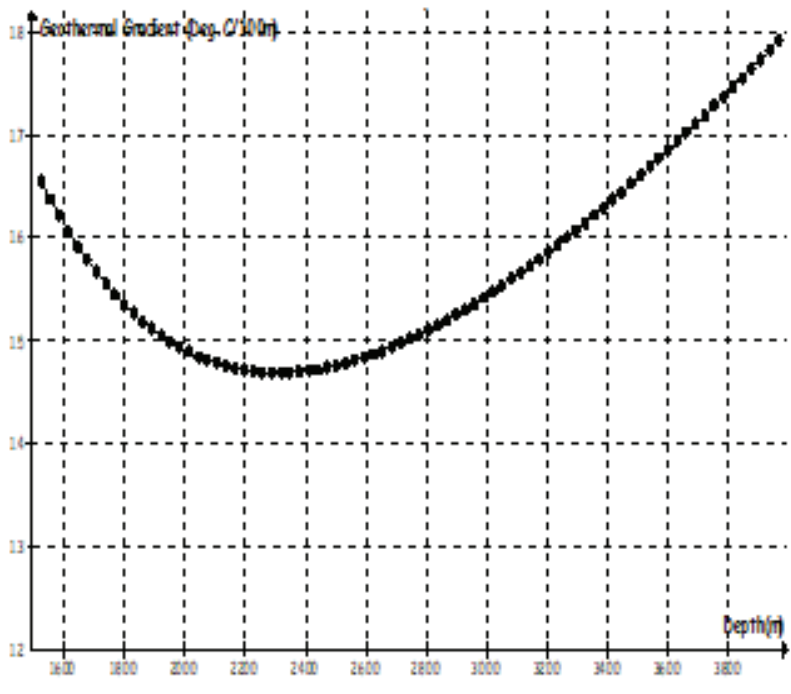

(b) Geothermal Gradient vs Depth plot for X-002

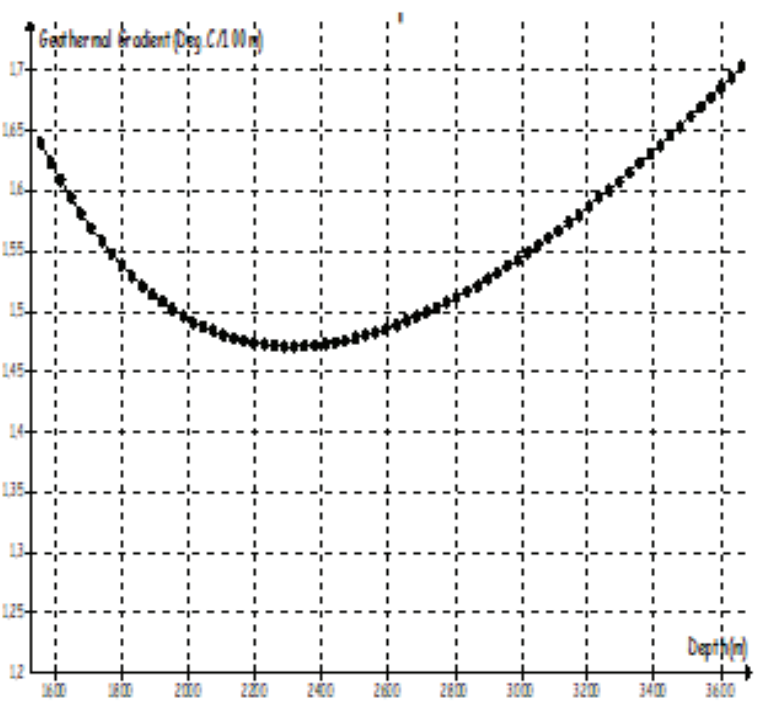

(d) Geothermal Gradient vs Depth plot for X-004

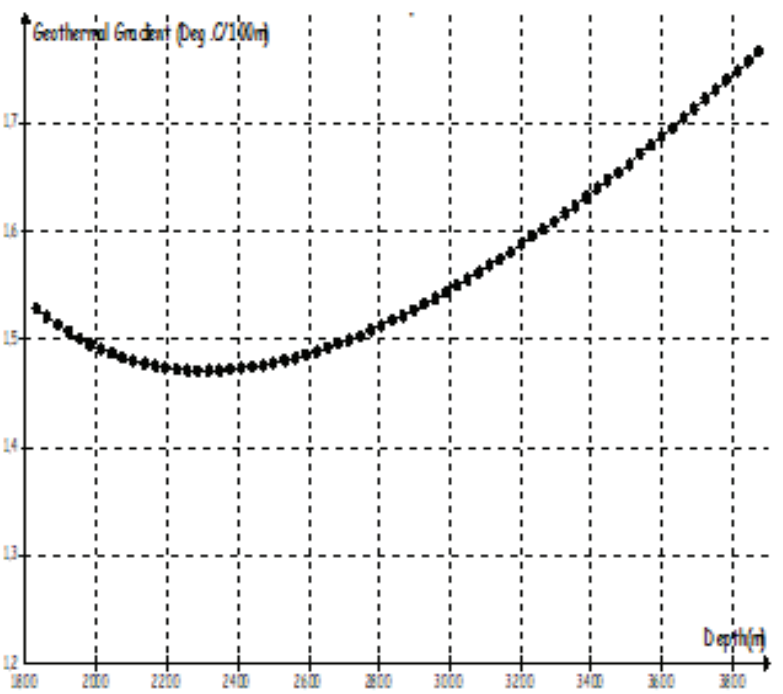

(f) Geothermal Gradient ws Depth plot for X-006

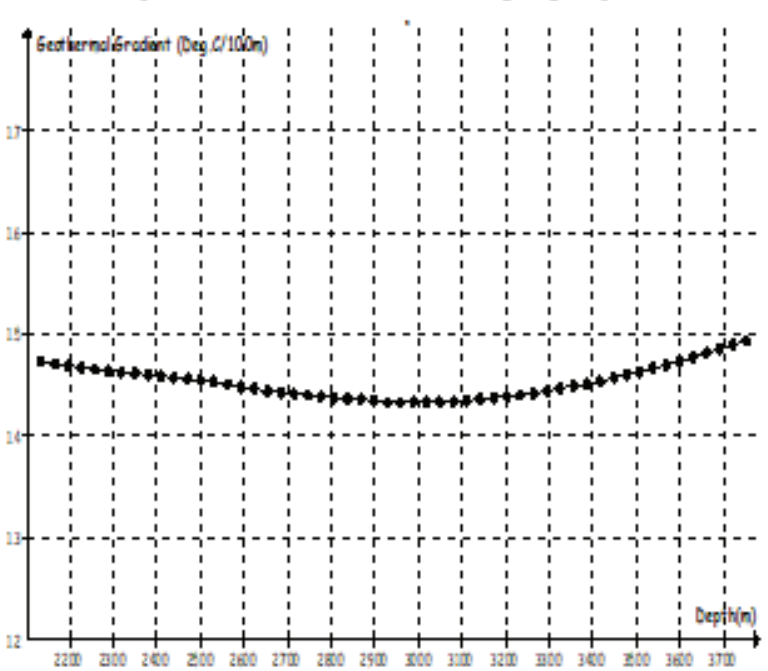

Figure 5. a, b, c, d, e, f: Geothermal gradient versus depth plots for Wells: X-001; X-002, X-003, X-004, X-005 and X-006. 


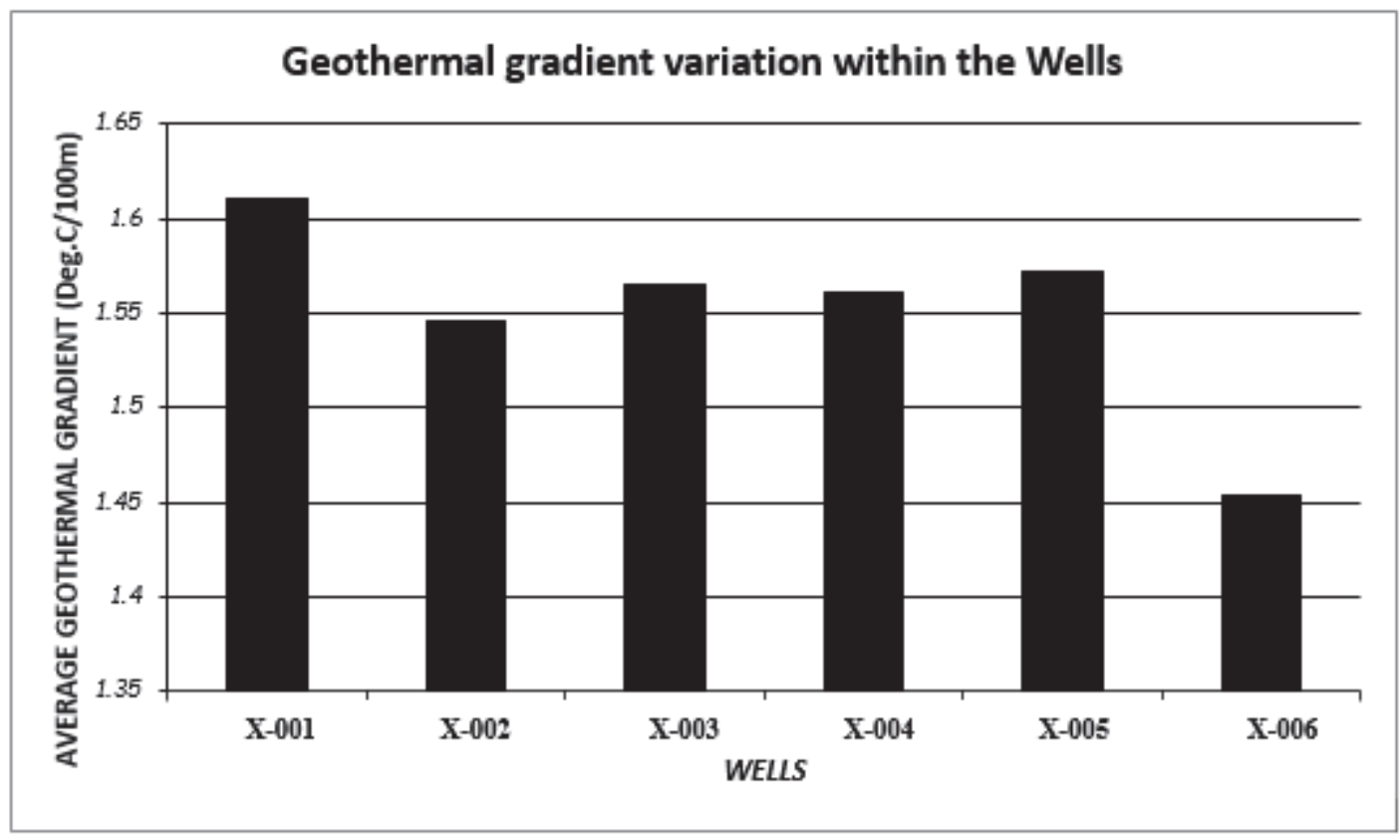

Figure 6. Geothermal gradient variation as a function of Well location. The figure shows clearly how geothermal gradient varies in the study area with respect to each well.

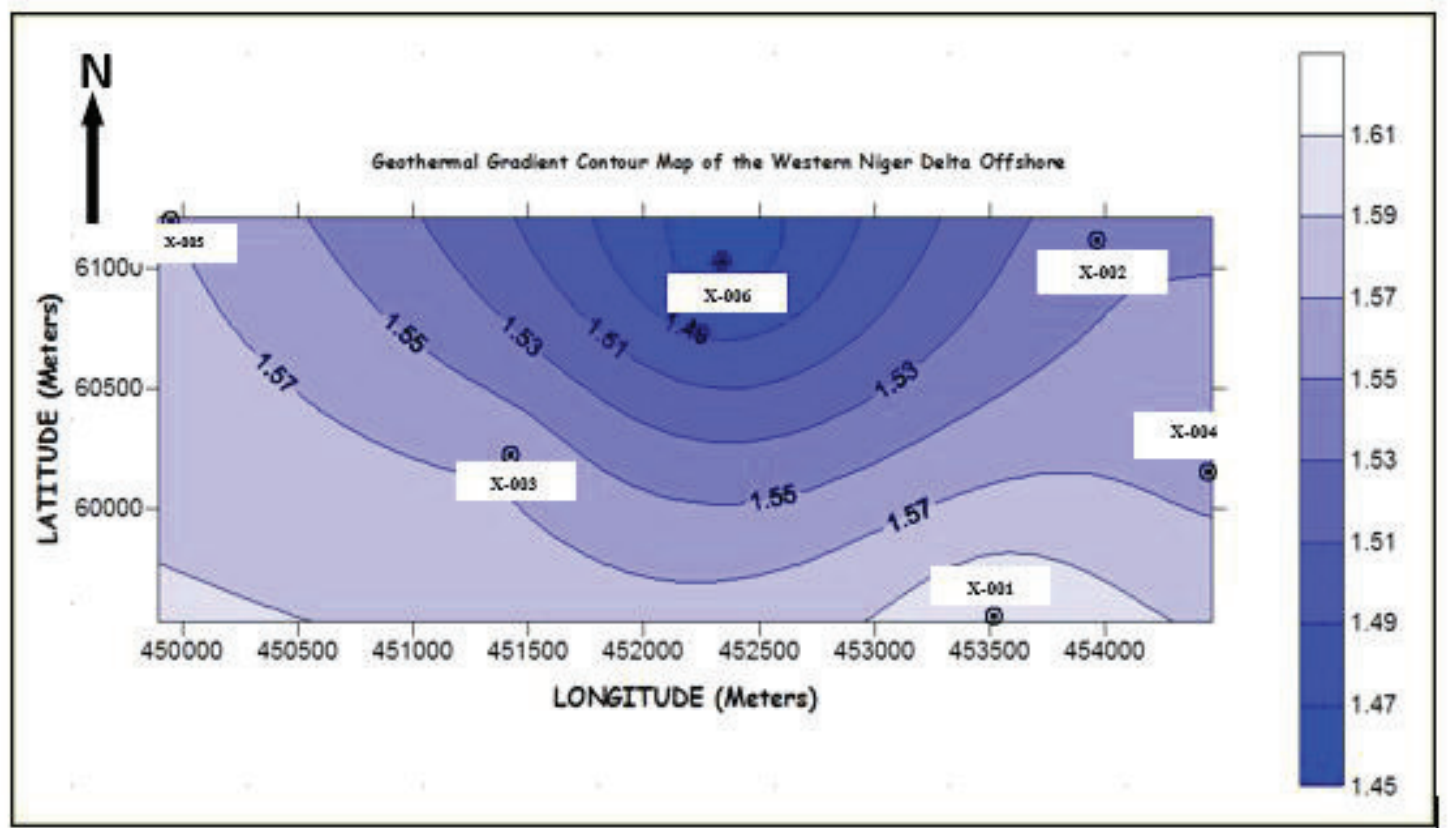

Figure 7. Contour map for the Geothermal gradient of the Western Niger Delta Offshore (Contours in $\left.{ }^{0} \mathrm{C} / 100 \mathrm{~m}\right)$. 




Figure 8. Geothermal heat flow (heat flux) contour map of the study area (Contours in $\mathrm{mW} / \mathrm{m}^{2}$ ).

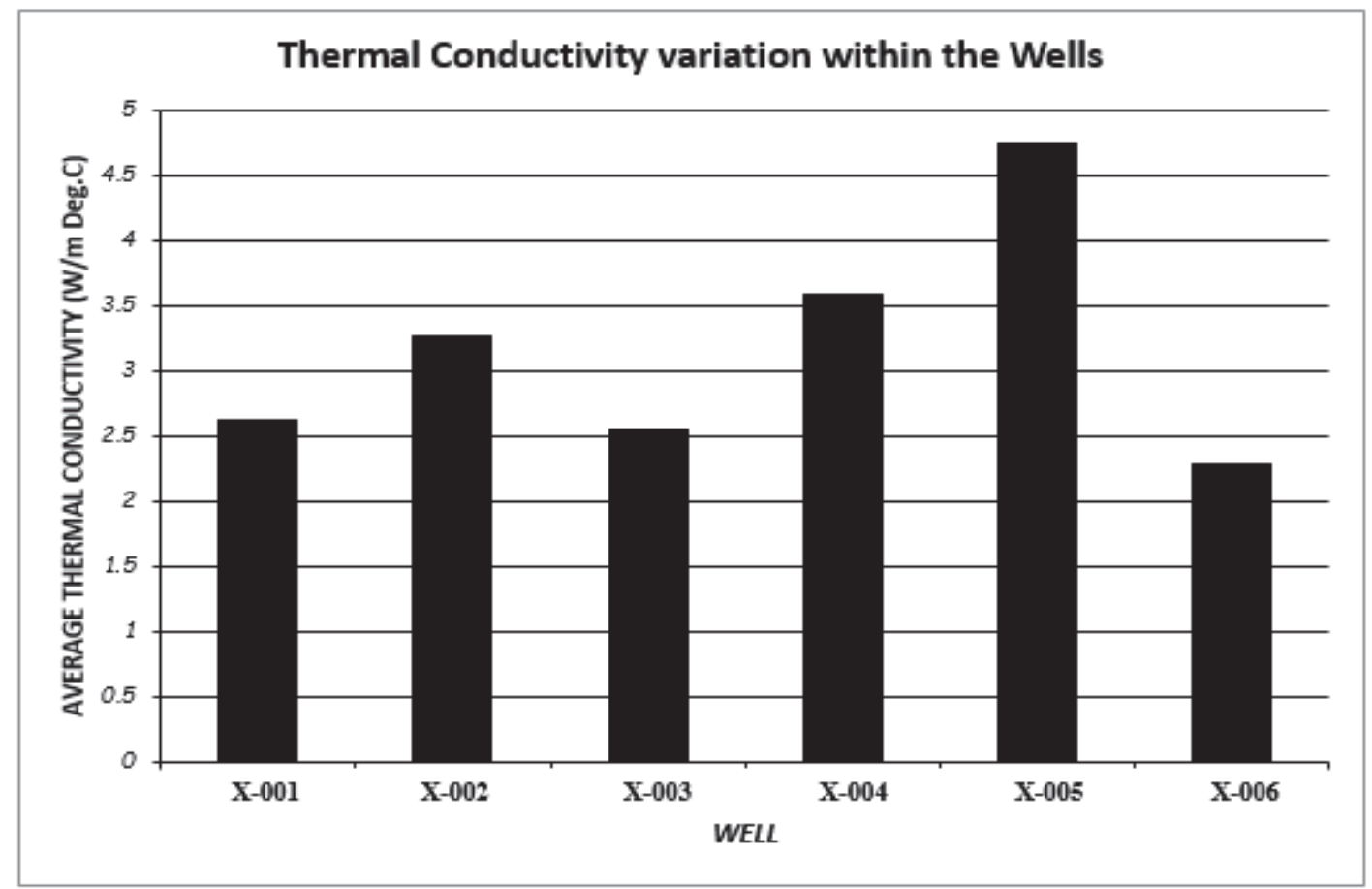

Figure 9. Thermal Conductivity variation as a Function of Well Location. 


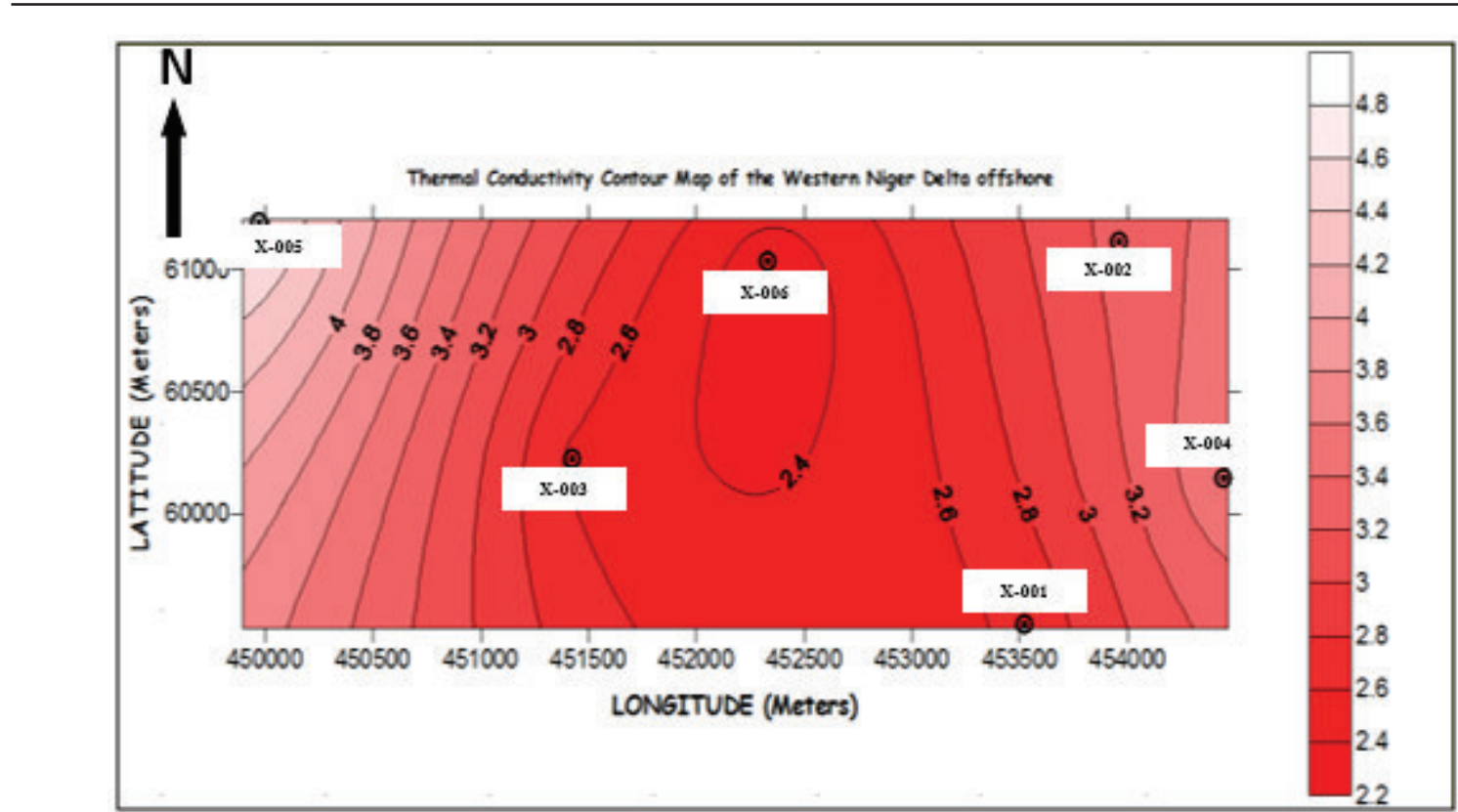

Figure 10. Contour map for thermal conductivity (K) of rocks in the Western Niger Delta (Contours in $\mathrm{W} / \mathrm{m}^{0} \mathrm{C}$ ).

\subsection{Discussion of result}

Geothermal gradient (GG) in the study area ranges from $1.45^{\circ} \mathrm{C} / 100 \mathrm{~m}$ to $1.61^{\circ} \mathrm{C} / 100 \mathrm{~m}$, with a simple average of $1.55^{\circ} \mathrm{C} / 100 \mathrm{~m}$ (table 2). The values obtained are comparable to the geothermal gradient range of 0.82 to $4.6^{\circ} \mathrm{C} / 100 \mathrm{~m}$ obtained by Akpabio et al., (2003) in the Niger Delta basin; 1.3 to $1.8^{\circ} \mathrm{C} / 100 \mathrm{~m}$ found in the centre of Niger Delta within the thick tertiary sediments obtained by (Nwachukwu, 1976); the range of $1.526^{\circ} \mathrm{C} / 100 \mathrm{~m}$ to $2.727^{\circ} \mathrm{C} / 100 \mathrm{~m}$ observed for the northern part of the Niger Delta obtained by Etim et al., (1996). A distinctive feature of the geothermal gradient map (Figure 7) is the low thermal gradient observed at the northern part of the study area where we have Well X-006 which increases outwards in all direction as we move further offshore. These differences may reflect changes in thermal conductivity of rocks as computed from sonic log for various well locations, ground water movement and endothermic reaction during diagenesis. The geothermal gradients are influenced by lithology or differential rate of sedimentation within the sedimentary column. The regions of low geothermal gradient correspond with areas of high sand percentage primarily because sands are better conductors than shale and therefore show a low thermal gradient (Akpabio et al., 2003). Therefore, it was inferred that sediments with a relatively high geothermal gradient $\left(1.55\right.$ to $\left.1.61^{\circ} \mathrm{C} / 100 \mathrm{~m}\right)$ will mature earlier (low oil window) than those with low thermal gradient values. By implication, a high geothermal gradient enhances the early formation of oil at relatively shallow burial depths, but causes the depth range of the oil window to be narrow, while low geothermal gradient causes the first formation of oil to begin at fairly deep subsurface levels, but makes the oil window broad (Emujakporue et al., 2009). The variation of geothermal gradient with depth for the six (6) wells (figure 5a-f) shows that the geothermal gradient initially decreases with depth but eventually starts to increase again as was observed for wells X-001 to X-005, except that of well X-006 which looks nearly linear. This initial decrease in geothermal gradient with depth is caused by compaction, with expulsion of formation water and decrease in porosity.

Figure 8 shows the geothermal heat flux (Q) contour map which shows the variation and distribution of heat flow within the study area plotted using the average heat flux values computed from each well (table 1, a-f). The estimated heat flux in the study area ranges from $33.16 \mathrm{mWm}^{-2}$ to $72.73 \mathrm{mWm}^{-2}$, with a simple average of 48.43 $\mathrm{mWm}^{-2}$ (table 2). These values are comparable to the range of $38.70-64.28 \mathrm{mWm}^{-2}$ (average of $51.49 \pm 3.2 \mathrm{mWm}^{-}$ ${ }^{2}$ ) obtained by Etim et al., (1996) for the Northern Niger Delta Basin; the range of $27.6-68.3 \mathrm{mWm}^{-2}$ (average of $43.92 \mathrm{mWm}^{-2}$ ) obtained by Ogagarue (2007) for the Western Niger Delta basin; and the range of $39.72-72.41$ $\mathrm{mWm}^{-2}$ (average of $56.07 \mathrm{mWm}^{-2}$ ) obtained by Etim and Akpabio (2009) for the North-western Niger Delta. From the heat flux contour map (Figure 8), it was observed that the heat flux values are low at the central part of the study area, but increases systematically outwards towards the western and eastern part of the study area, with Well X-005 characterized by a higher heat flux. This variation may be attributed to sediment thickness and/or hydrodynamics. Following the works of Lee and MacDonald (1963); Wang (1965) and Kaula (1966) based on heat flow distribution, which suggests a correlation between gravity (geoidal) undulations and the variations (low/high) of heat flow in an area. Such that observed depressions on the geoid correspond with regions of high heat flow while rises on the geoid correspond with regions of low heat flow. This however, implies that the depressions (gravity low) on the geoid are related to regions characterized by hotter and lighter materials while the 
rises (gravity high) in the geoid correspond to regions with colder and heavier materials (Lee and MacDonald, 1963; Wand 1965). As such, regions with high heat flux values correspond with zones of maximum sediment thickness while regions with low heat flux values correspond with zones of minimum sediment thickness. It can thus be inferred that the central part of the study area characterized by low heat flux has a lower sediment thickness compared to the western and eastern parts of the study area.

Also, thermal conductivity $(\mathrm{K})$ of rocks in the study area ranges from $2.28 \mathrm{~W} / \mathrm{m}^{0} \mathrm{C}$ to $4.76 \mathrm{~W} / \mathrm{m}^{0} \mathrm{C}$ with an average of $3.19 \mathrm{~W} / \mathrm{m}^{0} \mathrm{C}$ (table 2). These values fall within the thermal conductivity range of $1.1 \mathrm{~W} / \mathrm{m}^{0} \mathrm{C}$ to $6.2 \mathrm{~W} / \mathrm{m}^{0} \mathrm{C}$ obtained by Ogagarue (1998) from the western Niger Delta. From the thermal conductivity contour map (Figure 10), it was observed that thermal conductivity values are low in the central part of the study area, and increases systematically outwards towards the west and eastern part of the study area. This pattern of thermal conductivity variation in the study area suggests that probably there exists heavy crude oil at the central part of the study area and lighter crude oil as we move outward in all direction. It was also observed that in each well location, the thermal conductivity generally increases with depth. This is an indication that sonic velocity plays the major role in the control of thermal conductivity of sediments as temperature increases with depth, so does velocity also increases with depth. This may also be caused by variable lithology and fluid content (Majorowicz et al., 2014), or as a result of a decrease in porosity due to the fact that all pore fillers (i:e gases and liquids) are poor conductors. Therefore, thermal conductivity decreases with increasing porosity, showed that porosity decreases with increase in velocity and conversely the interval transit time. Thermal conductivity shows a direct relationship with geothermal heat flux, which implies that where there is a relatively low conductivity, geothermal heat flow is observed to be low (Well X-006, in table 1). Similarly, where there is relatively high conductivity, heat flow is observed to be high (Well X-005, in table 1). Thus, thermal conductivity show a linear relation with the heat flow, and an approximate inverse relation with the geothermal gradient of the area. Figure 9, shows thermal conductivity $(\mathrm{K})$ as a function of well location and shows clearly how thermal conductivity varies in the study area with respect to the six (6) wells.

With the available data, attempt were made to determine the regional temperature variation at certain depths in the wells. For this purpose, the temperatures at depths $6500 \mathrm{ft}(1982.5 \mathrm{~m})$ and $12,000 \mathrm{ft}(3660 \mathrm{~m})$ have been chosen and applied in the mapping of the isogeothermal patterns at these depths within the wells in the study area (Table 3 ). It should be noted that the geothermal gradient equation (equation 2) was used to predict subsurface temperatures at these depths where temperature measurement was originally not available.

Table 3 shows that temperatures at $6500 \mathrm{ft}(1982.5 \mathrm{~m})$ and $12,000 \mathrm{ft}(3660 \mathrm{~m})$ depths in the wells range from $55.82^{\circ} \mathrm{C}$ to $56.67^{\circ} \mathrm{C}$ and from $81.24^{\circ} \mathrm{C}$ to $89.39^{\circ} \mathrm{C}$ respectively. The temperature rise observed within these intervals is lowest in Well X-006, moderate in Well X-001, and highest for Well X-002, Well X-003, Well X-004 and Well $\mathrm{X}-005$.

Table 3. Regional temperature distribution at 1982.5m (6500ft) and 3660m (12000ft) in the Western Niger Delta Offshore.

\begin{tabular}{|c|c|c|c|c|c|}
\hline Wells & Temp at $6500 \mathrm{ft}\left({ }^{\circ} \mathrm{C}\right)$ & Comment & $\begin{array}{c}\text { Temp at } \\
12000 \mathrm{ft}\left({ }^{\circ} \mathrm{C}\right)\end{array}$ & Comment & $\begin{array}{l}\text { Temp Rise per } \\
5500 \mathrm{ft}\end{array}$ \\
\hline $\mathrm{X}-001$ & 56.66744444 & & 85.95001381 & $\begin{array}{l}\text { Predicted from } \\
\text { Average GG }\end{array}$ & 29.28256937 \\
\hline $\mathrm{X}-002$ & 56.66016667 & & 89.32344444 & & 32.66327777 \\
\hline X-003 & 56.64888889 & & 89.37311111 & & 32.72422222 \\
\hline X-004 & 56.65577778 & & 89.38905556 & & 32.73327778 \\
\hline $\mathrm{X}-005$ & 56.61944444 & & 89.30622222 & & 32.68677778 \\
\hline X-006 & 55.81636482 & $\begin{array}{c}\text { Predicted from } \\
\text { Average GG }\end{array}$ & 81.23811111 & & 25.42174629 \\
\hline
\end{tabular}

\section{Conclusions}

This study have shown how sonic log and continuous temperature log data can be used to estimate heat flow within a sedimentary basin using heat flow equations. Geothermal gradient (GG), geothermal heat flux $(\mathrm{Q})$ and thermal conductivity $(\mathrm{K})$ values estimated for the six (6) well were used to determine the pattern of heat flow distribution within the study area. From the analysis of results, it can be inferred that heat flow is lowest at the central part of the study area since geothermal heat flux (Q) and thermal conductivity $(\mathrm{K})$ values were observed low at this location (Well X-006) and heat flow increases towards the western parts (Well: X-003 \& X-005) and eastern parts (Well: X-002 \& X-004) of the study area as observed from values of geothermal heat flux (Q) and thermal conductivity $(\mathrm{K})$ estimated at these locations which were high. The study have also contributed to the existing literatures on heat flow estimation in a sedimentary basin by using a combination of three heat flow parameters (geothermal gradient, geothermal heat flux and thermal conductivity) in studying the heat flow dynamics in the region. 


\section{Acknowledgements}

The authors wish to express their gratitude to Shell Petroleum Development Company (SPDC) for providing the data used for this study. Special thanks also to Mr. Eze, Stanley (one of the authors) who proofread, edited and complied this paper for its publication.

\section{References}

Adedapo, J.O., Kurowska, E., Schoeneich, K., and Ikpokonte, A.E., (2013), “Geothermal gradient of the Niger Delta from recent studies", Int. J. of Sci. and Engr. Research (IJSER), Volume 4, Issue 11, pp. 39-45.

Akpabio, I.O., Ejedawe, J.E., Ebeniro, J.O., and Uko, E.D., (2003), "Geothermal gradients in the Niger Delta Basin from Continuous temperature logs", Global journal of Pure and Applied Sciences, 9 (2), pp. 265 - 272.

Akpabio, I.O., Ejedawe, J., and Ebeniro, J., (2013), “Thermal state of the Niger Delta", Proceedings, 38th workshop Geothermal Reservoir Engineering. Stanford University, Stanford, California, February, pp. 11 13.

Avbovbo, A.A., (1978), “Tertiary Lithostratigraphy of Niger Delta”, AAPG Bulletin, Vol. 62 (2), pp. 96-200.

Bullard, E.C., (1939), "Heat Flow in South Africa”, Proc. R. Soc., Ser. A. 173: pp. 474 - 502.

Bullard, E.C., (1947), “The time necessary for a borehole to attain temperature equilibrium", Monthly Notes of the Royal Astronomical Society, Vol. 5, pp. $127-130$.

Chapman, D.S., Keho, T.H., Bauer, M.S., and Picard, M.D., (1984), "Heat Flow in the Uinta Basin determined from Bottom Hole Temperature (BHT) Data", Geophysics. Vol. 49, no.4, pp. 453 - 466.

Corredor, F., Shaw, J.H., and Bilotti, F., (2005), "Structural styles in the deep-water fold and thrust belts of the Niger Delta", American Association of Petroleum Geologists Bulletin, Vol. 89, pp. 753 - 780.

Doust, H., (1989), “The Niger Delta hydrocarbon potential, a major Tertiary Niger Province", Proceedings of KNGMG Symposium, Coastal Lowstands, Geology and Geotechnology, The Hague, Kluiver Acad. Publ., Dordrecht; pp. 22-25.

Emujakporue, G.O., Ekine, A.S., Nwankwo, C.N., (2009), "Evaluation of the Hydrocarbon Maturity level of Oil Well in Sedimentary Basin of the Northern Niger Delta Nigeria”, J. Appl. Sci. Environ. Manage. Vol. 13 (3), pp. 79-82.

Etim, D.U., and Akpabio I.O., (2009), "Estimation of Heat Flow in the North-western Niger Delta Basin, Nigeria", Natural and Applied Sciences Journal, Vol. 10: No 1.

Etim, D.U., C.O. Ofoegbu, J.O. Ebeniro and C.C Chukwueke, (1996), "Present Day Heat Flow in the Northern Niger Delta, Nigeria", Nigerian Association of Petroleum Explorationist Bulletin, v. 4, p.

Evamy, B.D., J. Haremboure, R. Kammerling, W.A. Knaap, F.A. Molloy, and P.H. Rowlands, (1978), "Hydrocarbon habitat of tertiary Niger Delta", AAPG Bulletin; Vol.62, no.1, pp. 1 - 39.

Houbolt, J. J. and P. R. A. Wells, (1980), "Estimating Heat Flow in Oil Wells Based on a Relation Between Heat Conductivity and Sound Velocity", Geologie en Mijnbouw, Vol. 59, no.3, pp. 215 - 224.

Kaula, W.M., (1966), "Global Harmonics and Statistical Analysis of Gravimetry", American Geophysical Union Monography 9, pp. $87-190$.

Kutasov, I.M., and L.V., Eppelbaum (2005), "Determination of Formation temperature from bottom-hole temperature logs-a generalized Horner method”, Journal of Geophysics and Engineering, Vol. 2, pp. 90-96.

Lachenbruch, A.H., and Brewer, M.C., (1959), "Dissipation of the temperature effect of drilling a well in Arctic Alaska", US Geol. Surv. Bull. 1083-C, pp. 74-109.

Lachenbruch, A.H., and Sass, J.H., (1977), "Heat Flow in the United States and the Thermal Regime of the Crust, In the Earth's Crust”, Geophys. Monogr. Ser. 20. J.G. Heacock, ed. AGU, Washington, D.C.

Lawrence, S. R., Munday, S., and Bray, R., (2002), "Regional geology and geophysics of the Eastern Gulf of Guinea (Niger Delta to Rio Muni)", The Leading Edge, v. 21, (11), pp. 1112 - 1117.

Lee, W.H.K., and G.J.F. MacDonald., (1963), "The Global Variation of Terrestrial Heat Flow", Journal of Geophys. Research, 68, pp. $6481-6492$.

Majorowicz, J., Chan, J., Crowell, J., Gosnold, W., Heaman, L. M., Kück, J., Nieuwenhuis, G., Schmitt, D. R., Unsworth, M., Walsh, N., and Weides, S., (2014), "The first deep heat flow determination in crystalline basement rocks beneath the Western Canadian Sedimentary Basin”, Geophysical Journal International, Vol. 196, no. 3, pp. 1267-1905.

Michele, L.W.T., Ronald, R. Charpentier., and Michael, E. Beownfield., (1999), "The Niger Delta Petroleum system; Niger Delta province, Nigeria, Cameroon and Equitorial Guinea”, Africa Open file report, pp. 50-51.

Nadin, P.A., Kusznir, N.J., (1995), "Palaeocene uplift and Eocene subsidence in the Northern North Sea Basin from 2D forward and reverse stratigraphic modelling", Journal of the Geological society, Vol 152 (5); pp. 833-848.

Nwachukwu, J.I., and P.I. Chukwura., (1986), "Organic matter of Agbada Formation, Niger Delta, Nigeria", AAPG Bulletin, Vol.70, pp. $35-36$.

Nwachukwu, S.O., (1976), "Approximate Geothermal Gradients in the Niger Delta Sedimentary Basins", The 
American Association of Petroleum Geology. Bulletin. Vol. 60, No 7, pp. 1073-1077.

Ogagarue, D.O., (1998), "Heat flow estimate in western Niger Delta sedimentary basin", Unpublished M.Sc. Thesis, University of PortHarcourt, PortHarcourt, Nigeria.

Ogagarue, D.O., (2007), "Heat Flow Estimates in the Western Niger Delta Basin, Nigeria", Pacific Journal of Science and Technology. 8(2): pp. $261-266$.

Orife, J.M., and Avbovbo, A.A., (1982), "Stratigraphic and unconformity traps in the Niger Delta", American Association of Petroleum Geologists, Bulletin, Vol. 65, pp. 251-265.

Ramey, H.J. Jr., (1962), “Wellbore heat transmission”, J. Pet. Technology. 14, pp. 427-435.

Raymond, L.R., (1969), "Temperature distribution in a circulating drilling fluid”, J. Pet. Technology. 21, pp. 333341.

Stacher, P., (1995), "Present understanding of the Niger Delta hydrocarbon habitat", In: M.N. Oti and G.Postma (eds), Geology of deltas; A.A. Balkema, Rotterdam; pp. 257 - 267.

Tamuko, Omoniyi Johnson., (2008), “3D Seismic structural interpretation and Petrophysical Evaluation of X- field, Niger Delta Basin, Nigeria”, B.Tech Unpublished Project, Federal University of Technology Akure (FUTA).

Wang, C., (1965), "Some Geophysical Implications from Gravity and Heat Flow data", Journal of Geophys. Research, 70, pp. $5629-5634$.

Weber, K.J., and E.M. Daukoru., (1975), "Petroleum Geology of the Niger Delta", Proceedings of the 9th World Petroleum Congress, Tokyo, Vol. 2, pp. 202-221.

Whiteman, A.J., (1982), "Nigeria: Its Petroleum Geology, Resources and Potential”, Vol. 1 \& 2; Graham and Trotman, London, pp. 394. 